\title{
Modern Tools for Predicting Exchange Rates for Various Trade Activities
}

\author{
Sumathy Arjunan, S. Barani Chelvi, B. Venkata Srilatha
}

\begin{abstract}
Trade exchanged subordinates are appropriate for retail financial specialist, dissimilar to their over-the-counter cousins. In the OTC market, it is anything but difficult to become mixed up in the unpredictability of the instrument and the definite idea of what is being exchanged. Trade exchanged subsidiaries have two major focal points over the over-the-counter market ones. These are:

-Standardization: The trade has institutionalized terms and determinations for every subsidiary agreement, making it simple for the financial specialist to decide what number of agreements can be purchased or sold. Every individual agreement is additionally of a size that isn't overwhelming for the little financial specialist.

- Elimination of default hazard: The subsidiaries trade itself goes about as the counterparty for every exchange including a trade exchanged subsidiary, viably turning into the dealer for each purchaser, and the purchaser for each merchant. This kills the hazard that the counterparty to the subsidiary exchange may default on its commitments

Another characterizing normal for trade exchanged subsidiaries is their imprint to-showcase include, wherein increases and misfortunes on each subsidiary agreement is determined consistently. In the event that the customer has acquired misfortunes that have dissolved the edge set up, the individual in question should renew the necessary capital in a convenient way or hazard the subordinate position being auctions off by the firm. Keywords: Elimination of default hazard, OTC market
\end{abstract}

\section{INTRODUCTION}

Trade exchanged subsidiary agreements are institutionalized subordinate agreements, for example, fates and choices gets that are executed on a sorted out prospects trade. They are institutionalized and require installment of an underlying store or edge settled through a clearing house. Since the agreements are institutionalized, precise valuing models are frequently accessible. To comprehend which subsidiary is being exchanged an institutionalized naming show has been created by the trades, that shows the expiry month and strike value utilizing exceptional letter codes. A trade exchanged subsidiary is a money related instrument that exchanges on a controlled trade, and whose worth depends on the estimation

Revised Manuscript Received on December 30, 2019.

SumathyArjunan,, Assistant Professor, Department Of Science and Humanities,Bharath Institution Of Higher Education And Research

TamilNadu,India Email:sumi.renu@gmail.com

S. Barani Chelvi, Assistant Professor, Department Of Science and Humanities,Bharath Institution Of Higher Education And Research TamilNadu,India

B. Venkata Srilatha Assistant Professor, Department Of Science and Humanities,Bharath Institution Of Higher Education And Research TamilNadu,India bvsrilatha27@gmail.com of another benefit. Basically, these are subordinates that are exchanged a managed design. Trade exchanged subordinates

have become progressively well known in light of the points of interest they have over-the-counter (OTC) subsidiaries, for example, institutionalization, liquidity, and end of default chance. Fates and choices are two of the most prominent trade exchanged subordinates. These subordinates can be utilized to support introduction or estimate on a wide scope of monetary resources like items, values, monetary forms, and even financing costs.[1]-[4]

\section{A. BREAKING DOWN 'EXCHANGE TRADED DERIVATIVE'}

Trade exchanged subordinates are appropriate for retail financial specialist, dissimilar to their over-the-counter cousins. In the OTC market, it is anything but difficult to become mixed up in the unpredictability of the instrument and the definite idea of what is being exchanged. Trade exchanged subsidiaries have two major focal points over the over-the-counter market ones. These are: [5]-[9]

- Standardization: The trade has institutionalized terms and determinations for every subsidiary agreement, making it simple for the financial specialist to decide what number of agreements can be purchased or sold. Every individual agreement is additionally of a size that isn't overwhelming for the little financial specialist.

- Elimination of default hazard: The subsidiaries trade itself goes about as the counterparty for every exchange including a trade exchanged subsidiary, viably turning into the dealer for each purchaser, and the purchaser for each merchant. This kills the hazard that the counterparty to the subsidiary exchange may default on its commitments [10]

\section{RESULTS \& DISCUSSION}

Another characterizing normal for trade exchanged subsidiaries is their imprint to-showcase include, wherein increases and misfortunes on each subsidiary agreement is determined consistently. In the event that the customer has acquired misfortunes that have dissolved the edge set up, the individual in question should renew the necessary capital in a convenient way or hazard the subordinate position being auctions off by the firm. A list of the top 20 derivatives exchanges can be viewed below[11]-[15] 


\begin{tabular}{|c|c|c|c|c|c|}
\hline Rank & Exchange & $\begin{array}{l}\text { jan-dere } 2012 \\
\text { volume }\end{array}$ & $\begin{array}{l}\text { Annual \% } \\
\text { chargad }\end{array}$ & \begin{tabular}{|l} 
Dec 2012 \\
Open interest
\end{tabular} & $\begin{array}{l}\text { Annual } \\
\% \text { charged }\end{array}$ \\
\hline 1 & CME group & 2890036506 & $-14.7 \%$ & 6994737 & $-10.7 \%$ \\
\hline 2 & Euxex & 2291464606 & $-18.8 \%$ & 79088999 & $-14.1 \%$ \\
\hline 3 & $\begin{array}{l}\text { National stock exchange } \\
\text { of India }\end{array}$ & 201049348 & $-8.6 \%$ & 7786961 & $31.5 \%$ \\
\hline 4 & NYSE evronaxt & 1951376420 & $-14.5 \%$ & 46795803 & $-8.2 \%$ \\
\hline 5 & Korea exchange & 1835617727 & $-53.3 \%$ & 2553351 & $-27.6 \%$ \\
\hline 6 & 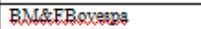 & 1635957604 & $9.0 \%$ & 63739705 & $23.0 \%$ \\
\hline 7 & CBOE holding & 1132316703 & $-6.8 \%$ & 16312240 & $12.7 \%$ \\
\hline 8 & Dardag OMX & 1115529138 & $-13.99 \%$ & 6770453 & $2.5 \%$ \\
\hline 9 & Moscow exchange & 1061835904 & $-3.4 \%$ & 3797729 & $18.1 \%$ \\
\hline 10 & $\begin{array}{l}\text { Multi commodity } \\
\text { exchange of india }\end{array}$ & 959613240 & $-19.8 \%$ & 2364256 & $44.5 \%$ \\
\hline 11 & $\begin{array}{l}\text { Dalin commodity } \\
\text { exchange }\end{array}$ & 633042976 & $119.0 \%$ & 2265275 & $982.8 \%$ \\
\hline 12 & Intercontinental exchange & 473895526 & $24.4 \%$ & 73128103 & $43.3 \%$ \\
\hline 13 & Shanghai future exchange & \begin{tabular}{|l|}
3653291533 \\
\end{tabular} & $18.5 \%$ & 1242174 & $16.1 \%$ \\
\hline 14 & $\begin{array}{l}\text { Zhengzhou commodity } \\
\text { exchange }\end{array}$ & 347091533 & $-14.6 \%$ & 1142206 & $22.1 \%$ \\
\hline 15 & ASX group & 205130168 & $15.4 \%$ & 16073167 & $21.0 \%$ \\
\hline 16 & BSE & 159719912 & $7879.5 \%$ & 68370 & $51.3 \%$ \\
\hline \begin{tabular}{|l|}
17 \\
\end{tabular} & TMXX group & 158996880 & $3.85 \%$ & 4231977 & $-2.9 \%$ \\
\hline
\end{tabular}

\section{Futures}

A prospects agreement is just an agreement determining that a purchaser buy or a dealer sell a basic resource at a predetermined amount, cost, and date later on. Prospects are utilized by the two hedgers and examiners to shield against or to benefit from value vacillations of the hidden resource later on. [16]-[20]

A heap of items can be exchanged on the fates trades, with agreements going from rural items, for example, domesticated animals, grains, soy beans, espresso, and dairy to stumble, gold, silver, copper to vitality wares, for example, raw petroleum and flammable gas to stock files and unpredictability records, for example, the S\&P, the Dow, Nasdaq, and the VIX, just as loan costs on Treasury notes and remote trade for a various cluster of major developing markets and cross cash sets. There are even fates dependent on guage climate and temperature conditions. Contingent upon the trade, each agreement is exchanged with its own details, settlement, and responsibility rules.

A rundown of the tradable prospects agreements can be found on the CME Group's site. [21]-[25]

\section{Alternatives}

Alternatives are subordinates that award the holder with the right, however not the commitment, to purchase or sell a fundamental resource at a pre-determined date and amount. The alternatives market has seen wonderful development since the primary institutionalized agreement was exchanged 1973. For example, the Options Clearing Corporation announced clearing 3.9 billion agreements in 2010 and 4.33 billion of every 2014. The Chicago Board Options Exchange (CBOE) is the biggest alternatives trade on the planet, with a normal day by day volume in 2014 of 5.3 million agreements being exchanged.

The Bottom Line
Trade exchanged subsidiaries offer greater liquidity, straightforwardness, and lower counter gathering danger than over-the-counter subordinates at an expense of agreement customization. The trade exchanged subordinates world incorporates fates, alternatives, and choices on fates contracts.

Presently since we have a fundamental thought with respect to what subsidiaries truly are and the capacity that they perform, it an opportunity to dive into somewhat more detail. Now, it is fundamental to present the idea of trade exchanged subordinates and over the counter subsidiaries. We have quickly brushed on them in the past not many articles. Notwithstanding, presently we will comprehend them in more detail. The thought is to get a handle on why this bifurcation among the sort of subsidiaries matters and how one can utilize the two kinds of subordinates.

Institutionalization

The characterizing highlight of the trade exchanged subsidiaries is that they are institutionalized agreements. How about we utilize a guide to clarify this. Suppose we need to fix the cost of $1260 \mathrm{kgs}$. of wheat that we hope to deliver in the gather season. We need to discover a purchaser in the subordinates showcase. Presently the issues that we will face are:

$\square$ It may be hard to discover a purchaser that needs a conveyance on precisely the same date that you intend to convey. There might be a couple of days to a great extent in the conveyance procedure

$\square$ It may be hard to get a purchaser in the accurate land territory that we are situated in. Obviously, purchasers can and will be all over the place. In any case, finding them in only seconds will be troublesome

$\square$ It may be hard to discover a purchaser that concurs on the definite terms of the agreement that you need to draw out. All things considered, the purchaser may feel that the agreement is one-sided towards you.

$\square$ It may be hard to get a purchaser that may need the careful sum for example $1960 \mathrm{kgs}$ of wheat. Rather, some purchaser may need $450 \mathrm{kgs}$ while others may need $2000 \mathrm{kgs}$.

The point, subsequently is, that creation purchasers and venders meet when they have incredibly explicit needs is a troublesome activity and is impossible on a trade.

Conversely, trade exchanged subordinates are institutionalized agreements. Each agreement will have a fixed lapse information, each agreement will be for a similar measure of amount for example $100 \mathrm{kgs}$ (expect). Henceforth, all the previously mentioned troubles become repetitive. [22] The greatest and separating component of trade exchanged subsidiaries is that they are institutionalized agreements. 
ThaiDex SET50 Exchange Traded Derivatives (TDEX.BK) $+$

\begin{tabular}{|c|c|c|c|c|c|c|}
\hline Date & open & high & low & Close & $\begin{array}{l}\text { adj } \\
\text { close }\end{array}$ & volume \\
\hline Mar 18 & 11.69 & 11.69 & 11.51 & 11.51 & 11.51 & 367100 \\
\hline Feb 18 & 11.49 & 11.79 & 11.06 & 11.69 & 11.69 & 5099400 \\
\hline $\operatorname{Jan} 18$ & 11.21 & 11.58 & 11.21 & 11.48 & 11.19 & 8297300 \\
\hline Dec 17 & 10.8 & 11.35 & 10.77 & 11.21 & 10.93 & 3032400 \\
\hline Nov 17 & 10.85 & 10.89 & 10.62 & 10.8 & 10.53 & 1893100 \\
\hline Oct 17 & 10.6 & 10.97 & 10.32 & 10.85 & 10.58 & 4606100 \\
\hline Sep 17 & 10.24 & 10.7 & 10.23 & 10.59 & 10.32 & 5761900 \\
\hline Aug 17 & 9.81 & 10.3 & 9.8 & 10.23 & 9.97 & 3839800 \\
\hline Jul 17 & 9.75 & 9.93 & 9.17 & 9.85 & 9.6 & 2302800 \\
\hline Jun 17 & 9.8 & 9.86 & 9.7 & 9.79 & 9.54 & 3351700 \\
\hline Mayl7 & 9.83 & 9.84 & 9.68 & 9.8 & 9.55 & 3349200 \\
\hline Apr 17 & 9.69 & 9.85 & 9.68 & 9.79 & 9.54 & 2862200 \\
\hline
\end{tabular}

\section{CONCLUSION}

To conclude it is important to note that any derivative that may be traded in different markets, the main aim of the trader is to earn profits rather than losses from their investment.

Therefore the trader must keep a track of the prices of the derivatives in order to earn a better return.

\section{REFERENCES}

1. Vasanthi, S. \& Rabiyathul Basariya, S. 2019, "Influence of value analysis and cross training in industry", International Journal of Engineering and Advanced Technology, vol. 8, no. 6, pp. 1810-1811.

2. Velvizhi, R., Sri Gowtham, S. \& Jeya Priya, D. 2019, "Examination of early feedbacks for effective product retailing on E-commerce websites", International Journal of Engineering and Advanced Technology, vol. 8, no. 6 Special Issue 2, pp. 703-706.

3. Anuradha, C., Pothumani, S. \& Kavitha, R. 2019, "A novel method towards E-commerce", International Journal of Engineering and Advanced Technology, vol. 8, no. 6 Special Issue 2, pp. 535-538.

4. Thomas, J. \& Rabiyathul Basariya, S. 2019, "A study on the issues of financial ratio analysis", Indian Journal of Public Health Research and Development, vol. 10, no. 3, pp. 1079-1081.

5. Ramachandran, S. \& Rabiyathul Basariya, S. 2019, "Online marketing - study on customer satisfaction and relationship", Indian Journal of Public Health Research and Development, vol. 10, no. 3, pp. 1072-1078.

6. Priya, R., Vinothini, G. \& Cor Jesu, C.D. 2019, "The mentor-protégé relationship for professional growth", Journal of Advanced Research in Dynamical and Control Systems, vol. 11, no. 9 Special Issue, pp. 1110-1119.

7. Jannifer Rani, N., Bina Pani, S. \& Nimisha, N.S. 2019, "A study on money back polices available in LIC", Journal of Advanced Research in Dynamical and Control Systems, vol. 11, no. 9 Special Issue, pp. 833-839.

8. Saillaja, V., Jhansi Rani, K. \& Catherine, R. 2019, "Global marketing management planning and organization", Journal of Advanced Research in Dynamical and Control Systems, vol. 11, no. 9 Special Issue, pp. 489-493.

9. Saillaja, V., Jhansi Rani, K. \& Catherine, R. 2019, "The new phase of marketing information system", Journal of Advanced Research in Dynamical and Control Systems, vol. 11, no. 9 Special Issue, pp. 482-488.

10. Thoufiqulla \& Raju, D.V. 2019, "Perception of indian investor towards investment in mutual funds with special reference to mip funds", Journal of Advanced Research in Dynamical and Control Systems, vol. 11, no. 5, pp. 177-183.
11. Jasmine, K.R.M. \& Basariya, S.R. 2018, "A study on the customers benefits on mutual funds", International Journal of Civil Engineering and Technology, vol. 9, no. 4, pp. 45-48.

12. Vasanthi, S. \& Basariya, S.R. 2019, "Pros and cons of on the job training versus off the job training", International Journal of Scientific and Technology Research, vol. 8, no. 10, pp. 671-674.

13. Pavithra, J. \& Ganesan, M. 2016, "A study on awareness and impact of micro-financial schemes", International Journal of Applied Business and Economic Research, vol. 14, no. 8, pp. 5449-5460.

14. Pavithra, J., Dilli Babu, P. \& Ambuli, T.V. 2014, "A study on budgetary control at Maruti Service Masters, Chennai", International Journal of Applied Business and Economic Research, vol. 12, no. 2, pp. 151-161.

15. Gunaraja, T.M. \& Venkatrama Raju, D. 2018, "Determining factors of organisational climate with reference to leadership styles", International Journal of Mechanical Engineering and Technology, vol. 9, no. 9, pp. 1327-1332.

16. Gunaraja, T.M. \& Venkatrama Raju, D. 2018, "The role of job satisfaction and training of employees in determining organisational climate of a selected industry", International Journal of Civil Engineering and Technology, vol. 9, no. 8, pp. 1266-1269.

17. Aarathy, T.S. \& Raju, D.V. 2018, "Performance appraisal and its effects on employees with respect to it sector in Chennai city", International Journal of Civil Engineering and Technology, vol. 9, no. 6, pp. 1535-1538.

18. Aarathy, T.S. \& Raju, D.V. 2018, "Employee perception towards performance appraisal system in IT sector", International Journal of Mechanical Engineering and Technology, vol. 9, no. 5, pp. 131-135.

19. Porselvi, W., Jublee, D. \& Sivanesan, G. 2018, "A study on factors influencing adoption of technology and innovation in banking industry, tamilnadu, India", International Journal of Mechanical Engineering and Technology, vol. 9, no. 5, pp. 789-800.

20. Akessa, G.M. and Dhufera, A.G., 2015. Factors That Influences Students Academic Performance: A Case of Rift Valley University, Jimma, Ethiopia. Journal of Education and Practice, 6(22), pp.55-63.

21. Miller, G. and Shih, C.C., 1999. A faculty assessment of the academic rigor of on-and off-campus courses in agriculture. Journa of Agricultural Education, 40, pp.57-65.

22. Tsinidou, M., Gerogiannis, V. and Fitsilis, P., 2010. Evaluation of the factors that determine quality in higher education: an empirica study. Quality Assurance in education, 18(3), pp.227-244.

23. Farooq, M.S., Chaudhry, A.H., Shafiq, M. and Berhanu, G., 2011 Factors affecting students' quality of academic performance: a case of secondary school level. Journal of quality and technology management, $7(2)$, pp.1-14

24. Fitsilis, P., Gerogiannis, V. and Anthopoulos, L., 2014. Ontologies for software project management: a review. Journal of Software Engineering and Applications, 7(13), p.1096.

25. Adams, J.D. and Jaffe, A.B., 1996. Bounding the effects of $R \& D$ : an investigation using matched establishment-firm data(No. w5544). National bureau of economic research.

\section{AUTHORS PROFILE}

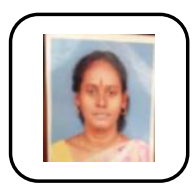

SumathyArjunan Assistant Professor, Department Of Science and Humanities,Bharath Institution Of Higher Education And Research TamilNadu,India

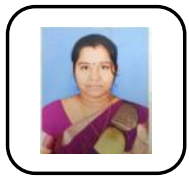

S. Barani Chelvi Assistant Professor, Department Of Science and Humanities,Bharath Institution Of Higher Education And Research TamilNadu,India

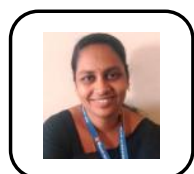

B. Venkata Srilatha Assistant Professor, Department Of Science and Humanities, Bharath Institution of Higher Education And Research TamilNadu,India 